\title{
Structural and electrical properties of the high temperature superconducting system $\mathrm{Bi}_{2} \mathrm{Ba}_{2} \mathrm{Ca}_{2} \mathrm{Cu}_{3} \mathrm{O}_{10+\delta}$
}

Khalid Hamdi Razeg

Department of Physics

University of Tikret

\author{
Kareem D. Alazawi \\ Al-Door Institute of Technology
}

\section{Mahmood Ahmad Hmood \\ Department of Physics \\ University of Mousl}

Received

22 / 03 / 2010
Accepted

14 / 09 / 2010

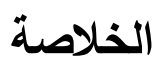

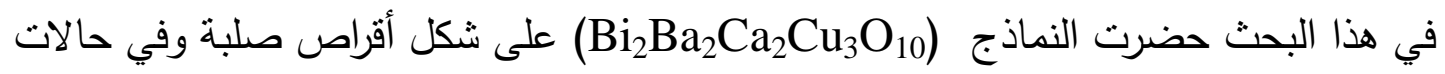

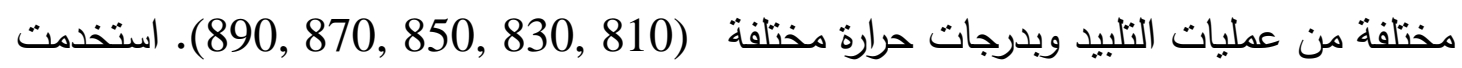

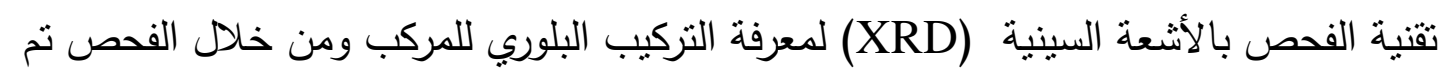
معرفة ان الحصول على تركيب تتزاكونال مع معلمات الثبيكة (a=b=5.42A A

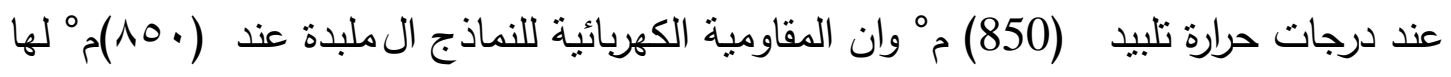

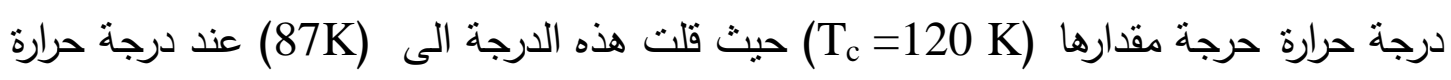

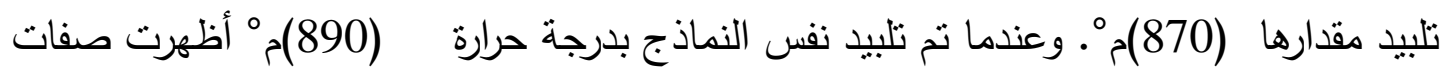

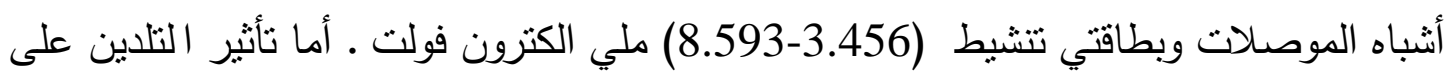

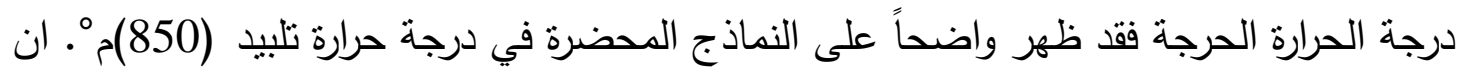

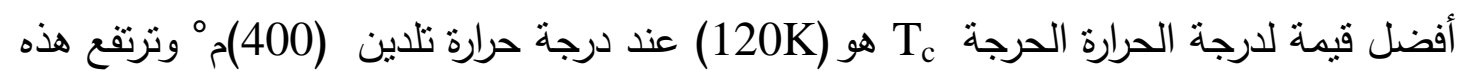

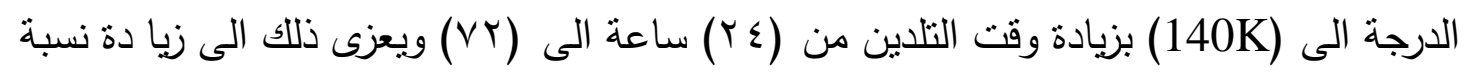
الأوكسجين ونمو طبقة (Cu-O) في الخلية.

\section{Abstract}

Samples of the high temperature superconducting system, $\mathrm{Bi}_{2} \mathrm{Ba}_{2} \mathrm{Ca}_{2} \mathrm{Cu}_{3} \mathrm{O}_{10}$, were prepared by solid state reaction method with different sintering temperatures $(810,830,850,870,890) \mathrm{C}^{\circ}$. X-ray 
diffraction technique was used to examine the structure of the compound and showed that the sample prepared with sintering temperature at $850 \mathrm{C}^{\circ}$ exhibits tetragonal phase with the lattice parameters $\mathrm{a}=\mathrm{b}=5.42 \mathrm{~A}^{\mathrm{o}}, \mathrm{c}=$ $34.13 \mathrm{~A}^{\text {o. }}$ The electrical resistivity measurements exhibited that the sample prepared at $850 \mathrm{C}^{\circ}$ its critical temperature was $\mathrm{T}_{\mathrm{c}}=120 \mathrm{~K}$ and decreases to $87 \mathrm{~K}$ when prepared at $870 \mathrm{C}^{\circ}$. However when the same sample prepared at $890 \mathrm{C}^{\circ}$ it showed semiconducting behavior with two activation energies $(8.593$ - 3.456)meV. The effect of annealing on critical temperature has been investigated on the sample which was prepared at $850 \mathrm{C}^{0}$. The best value of $\mathrm{T}_{\mathrm{c}}$ was $(132) \mathrm{K}$ at the annealing temperature $400 \mathrm{C}^{\mathrm{o}}$, and rises to $140 \mathrm{~K}$ with increasing the annealing time from $24 \mathrm{hrs}$ to $72 \mathrm{hrs}$ and this increase might be caused by the increase of oxygen content or by intergrowths of a large number $\mathrm{Cu}-\mathrm{O}$ layers in the cell.

Keywords: High temperature superconductors, semiconductors, electrical resistivity, annealing temperature.

\section{Introduction:}

The discovery of superconductivity between $7 \mathrm{~K}$ and $22 \mathrm{~K}$ in the Bi$\mathrm{Sr}-\mathrm{Cu}-\mathrm{O}$ compound has been reported by Michel et al in 1987 [1]. Because of the intense interest in the $90 \mathrm{~K}$ material at that time, their report did not attract widespread interest. However, attention quickly was focused on the Bi-containing superconductor in January 1988, when Meada et al [2] and $\mathrm{Chu}$ et al [3] reported that adding $\mathrm{Ca}$ to the $\mathrm{Bi}-\mathrm{Sr}-\mathrm{Cu}-$ $\mathrm{O}$ system produced material that was superconducting above liquid nitrogen temperature $77 \mathrm{~K}$. Since then great attention was focused on the series compound $\mathrm{Bi}-\mathrm{Sr}-\mathrm{Cu}-\mathrm{O}$ which shows superconductivity around $105 \mathrm{~K}$ [4]. The properties of these systems show that superconductors with structural formula $\mathrm{Bi}_{2} \mathrm{Sr}_{2} \mathrm{CuO}_{6}, \mathrm{Bi}_{2} \mathrm{Sr}_{2} \mathrm{CaCu}_{2} \mathrm{O}_{8}$ and $\mathrm{Bi}_{2} \mathrm{Sr}_{2} \mathrm{Ca}_{2} \mathrm{Cu}_{3} \mathrm{O}_{10}$ have $\mathrm{T}_{c}$ values of $10 \mathrm{~K}, 85 \mathrm{~K}$, and $110 \mathrm{~K}$ respectively[5].

The aim of this paper is to investigate the structural and electrical properties of the superconducting compound $\mathrm{Bi}-\mathrm{Ba}-\mathrm{Ca}-\mathrm{Cu}-\mathrm{O}$ prepared using a special preparation method. In this method, the compound was annealed at several temperatures and for different annealing times to study the effect of preparation conditions on the structural and electrical properties of the superconducting system.

\section{Experimental:}

High temperature $\mathrm{Bi}_{2} \mathrm{Ba}_{2} \mathrm{Ca}_{2} \mathrm{Cu}_{3} \mathrm{O}_{10}$ superconductor samples were prepared using the solid state reaction method. The appropriate quantities of highly pure $\mathrm{Bi}_{2} \mathrm{O}_{3}, \mathrm{CaCO}_{3}, \mathrm{BaCO}_{3}$ and $\mathrm{CuO}$ have been determined in stoicheometric ratio of $\mathrm{Bi}: \mathrm{Ba}: \mathrm{Ca}: \mathrm{Cu}=2: 2: 2: 3$. 
The mixture was ground with isopropanol by using an agate mortar. The well mixed powder of these oxides was calcimined at $(800) \mathrm{C}^{\mathrm{o}}$. The mixture was pressed into approximately $1 \mathrm{gm}$ pellets, with $1.1 \mathrm{~cm}$ diameter and $0.17 \mathrm{~cm}$ thickness. The pressed pellets were initially heated in air from room temperatures to different sintering temperatures $(810,830,850,870,890) \mathrm{C}^{\mathrm{o}}$ for $24 \mathrm{hr}$ and then slowly cooled $\left(30 \mathrm{C}^{\mathrm{O}} / \mathrm{hr}\right)$ to room temperature. Finally, the sample pellets were annealed at different temperatures $(100,200,300,400,500,600) \mathrm{C}^{\circ}$, and for different times $(24,48,72,96)$ hrs.

$\mathrm{X}$-ray diffraction patterns of these samples at room temperature were obtained using Phillips X-ray diffractometer with $\mathrm{CuK \alpha}$ source and $1.5418 \mathrm{~A}^{\mathrm{o}}$ wavelength. The electrical resistivity method has been used to determined the critical temperature. The electrical resistivity was measured using the standard four-probe method. Electrical contacts were made using fine copper wires and conductive silver paste. The oxygen content in the sample was measured by using iodemetric method[6].

\section{Results and Discussion:}

X-ray diffraction patterns of $\mathrm{Bi}_{2} \mathrm{Ba}_{2} \mathrm{Ca}_{2} \mathrm{Cu}_{3} \mathrm{O}_{10+\delta}$. $\mathrm{Fig}(1)$ show the existence of single tetragonal phase for the sample that was prepared at $810 \mathrm{C}^{\circ}$ as shown in Fig(1). A computer program was used to calculate the values of the lattice parameters $a, b$ and $c$. Table (I) shows the values of these parameters. Similar behavior has been shown by the sample which was prepared at $850 \mathrm{C}^{\circ}$. This was attributed to the change in the structure from orthorhombic to tetragonal with lattice parameters $\mathrm{a}=\mathrm{b}=5.42 \mathrm{~A}^{\mathrm{o}}$ and $\mathrm{c}=34.13 \mathrm{~A}^{\mathrm{0}}[7,8,9]$

The change in the structure from tetragonal to orthorhombic phase occurred also in the samples which were prepared at $870 \mathrm{C}^{\circ}$ as shown in table I. This means that $870 \mathrm{C}^{\circ}$ was not the ideal sintering temperature. The change in the structure was observed in samples with sintering temperature $890 \mathrm{C}^{\mathrm{o}}$. Similar results were obtained by other authors [10-13] for different compounds. They pointed out that the elongating in the c-axis plays a crucial role in high temperature superconductors. The increase in sintering temperature leads to creation of more oxygen deficiency, which is very important factor for the presence of high temperature superconductivity.

The electrical resistivity at various temperature was measured for all samples and the results are shown in fig.(2). The superconducting transition temperatures $T_{c}$ are shown in table II. It is clear from table II that the value of $T_{c}$ increases with increasing the sintering temperature, these results are related to the configuration of possible $\mathrm{Cu}-\mathrm{O}$ planes or chains in the compound.

But the sample which was prepared at $870 \mathrm{C}^{0}$ showed a decreasing in the value of $T_{c}$ while the sample which was prepared at $890 \mathrm{C}^{\circ}$, showed semiconducting behavior with two activation energies 8.593 and 3.456 
meV, as shown in Fig.(3). The first activation energy is due to hopping between localized states, while the second is due to transport to deeper distances in the gap but with less energy. We attribute that to the change in the structure which leads to the change in superconducting behavior. These results are in good agreement with the result for $\mathrm{Bi}-2223$ compounds [14]. The best value of $T_{c}$ was $120 \mathrm{~K}$ for the sample prepared at $850 \mathrm{C}^{0}$, since these samples were annealed at different annealing temperatures. The best value of $\mathrm{T}_{c}$ was obtained for annealing temperature of $400 \mathrm{C}^{0}$ for $24 \mathrm{hr}$ as shown from Fig (4) and Fig.(5), and it rises from $120 \mathrm{~K}$ to $132 \mathrm{~K}$.

The increasing in $\mathrm{T}_{\mathrm{c}}$ with annealing temperature, (see table III) depends on the increase in oxygen content, which plays the very important role in increasing or decreasing $\mathrm{T}_{\mathrm{c}}$. The increase might be caused by decreasing of the structural defects and also due to intergrowth of a large number of $\mathrm{Cu}-\mathrm{O}$ layers in the unit cell. Similar behavior has been detected by Fathi et al [15].

The relation between resistivity and temperature for the sample annealed at $400 \mathrm{C}^{\circ}$ for different times are shown in fig.(5), it is clear that, as the time of annealing is increased the value of $T_{c}$ increases and saturates at the annealing time of $72 \mathrm{hr}$ as shown in table IV. The increase in $T_{c}$ value with increasing annealing temperature leads to the increase in the charge carriers, the Cooper pairs, which is due to electron-phonon coupling[5].

\section{Conclusion:}

Superconductivity is shown to be possible in the tetragonal structure and orthorhombic structure, depending to the sintering temperature. The best value of sintering temperature is $850 \mathrm{C}^{\mathrm{o}}$ which gives the best structure and electrical properties. The change in the structure occurs at sintering $890 \mathrm{C}^{\mathrm{o}}$ which is due to the change in phase. The best value of $T_{c}$ is obtained at annealing temperature $400 \mathrm{C}^{\circ}$ which affects the oxygen content. The value of $T_{c}$ increase and saturates at annealing time $72 \mathrm{hr}$. Annealing can cause increase the $T_{c}$ it causes the decrease in the structural defects.

\section{Table I}

Lattice parameters for sintering temperature to preparing $\mathrm{Bi}_{2} \mathrm{Ba}_{2} \mathrm{Ca}_{2} \mathrm{Cu}_{3} \mathrm{O}_{10+\delta}$ superconductors.

\begin{tabular}{|c|c|c|c|}
\hline \multirow{2}{*}{$\mathrm{T}\left(\mathrm{C}^{\mathrm{o}}\right)$} & \multicolumn{3}{|c|}{ Lattice constant } \\
\cline { 2 - 4 } & $\mathrm{a}\left(\mathrm{A}^{\mathrm{o}}\right)$ & $\mathrm{b}\left(\mathrm{A}^{\mathrm{o}}\right)$ & $\mathrm{C}\left(\mathrm{A}^{\mathrm{o}}\right)$ \\
\hline 810 & 5.41 & 5.41 & 30.75 \\
\hline 830 & 5.45 & 5.45 & 31.03 \\
\hline 850 & 5.42 & 5.42 & 34.13 \\
\hline 870 & 5.43 & 5.40 & 30.99 \\
\hline 890 & 5.42 & 5.40 & 30.88 \\
\hline
\end{tabular}


Table II

Critical temperatures for examined samples $\mathrm{Bi}_{2} \mathrm{Ba}_{2} \mathrm{Ca}_{2} \mathrm{Cu}_{3} \mathrm{O}_{10+\delta}$ superconductors with different sintering temperature.

\begin{tabular}{|c|c|c|}
\hline $\mathrm{T}\left(\mathrm{C}^{\mathrm{o}}\right)$ & $\mathrm{T}_{\mathrm{c}}(\mathrm{K})$ & $10+\delta$ \\
\hline 810 & 95 & 10.12 \\
\hline 830 & 100 & 10.17 \\
\hline 850 & 120 & 10.22 \\
\hline 870 & 87 & 10.71 \\
\hline 890 & $\begin{array}{l}\text { Semiconductors: } \\
\mathrm{E}_{\text {act }}(1)=8.593 \mathrm{mev} \\
\mathrm{E}_{\text {act }}(2)=3.456 \mathrm{mev}\end{array}$ & 10.27 \\
\hline
\end{tabular}

$\mathrm{T}=$ sintering temperature.

$\mathrm{T}_{\mathrm{c}}=$ critical temperature.

$10+\delta=$ Oxygen content.

Table III

Critical temperatures for annealed $\mathrm{Bi}_{2} \mathrm{Ba}_{2} \mathrm{Ca}_{2} \mathrm{Cu}_{3} \mathrm{O}_{10+\delta}$ superconductors at 850 $\mathrm{C}^{\mathbf{0}}$ with different annealing temperature.

\begin{tabular}{|c|c|c|}
\hline $\begin{array}{c}\text { Annealing } \\
\text { Temperature } \mathrm{T}\left(\mathrm{C}^{\mathrm{o}}\right)\end{array}$ & $\begin{array}{c}\text { Critical Temperature } \\
\mathrm{T}_{\mathrm{c}}(\mathrm{K})\end{array}$ & $10+\delta$ \\
\hline 100 & 125 & 10.25 \\
\hline 200 & 127 & 10.29 \\
\hline 300 & 130 & 10.30 \\
\hline 400 & 132 & 10.38 \\
\hline 500 & 90 & 9.97 \\
\hline 600 & 82 & 9.93 \\
\hline
\end{tabular}

Table IV

Critical temperatures for annealed $\mathrm{Bi}_{2} \mathrm{Ba}_{2} \mathrm{Ca}_{2} \mathrm{Cu}_{3} \mathrm{O}_{10+\delta}$ superconductors at 850

$\mathrm{C}^{0}$ with different annealing time for best annealing temperature $\left(400 \mathrm{C}^{0}\right)$.

\begin{tabular}{|c|c|c|}
\hline $\mathrm{T}_{\mathrm{c}}(\mathrm{K})$ & Annealing time $(\mathrm{hr})$ & $10+\delta$ \\
\hline 132 & 24 & 10.38 \\
\hline 134 & 48 & 10.40 \\
\hline 136 & 72 & 10.42 \\
\hline 136 & 96 & 10.42 \\
\hline
\end{tabular}


Structural and electrical properties of the high temperature superconducting ...

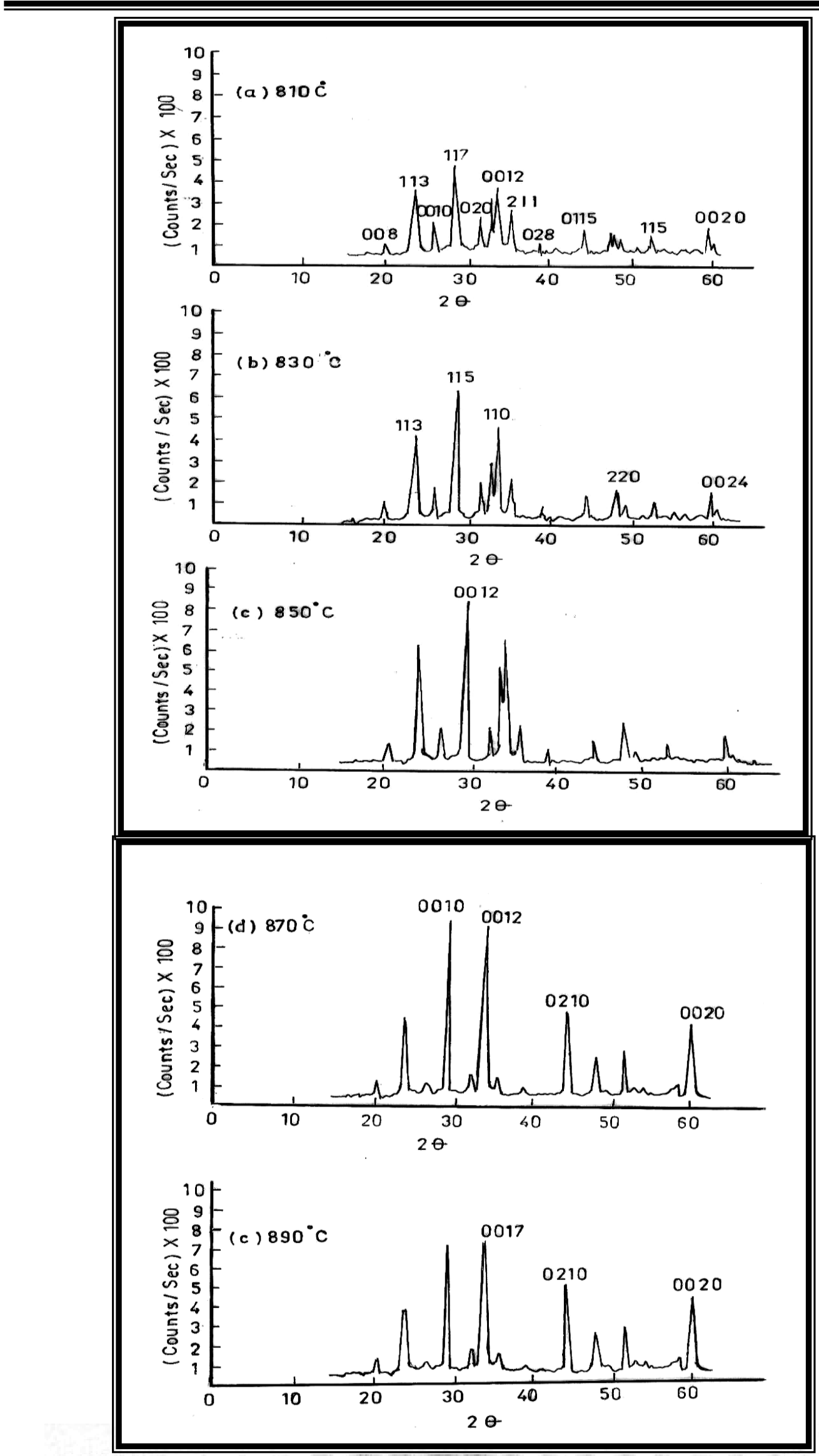

Fig(1): X-ray diffraction pattern of $\mathrm{Bi}_{2} \mathrm{Ba}_{2} \mathrm{Ca} 2 \mathrm{Cu} 3 \mathrm{O}_{10}$ at different sintering temperatures. 


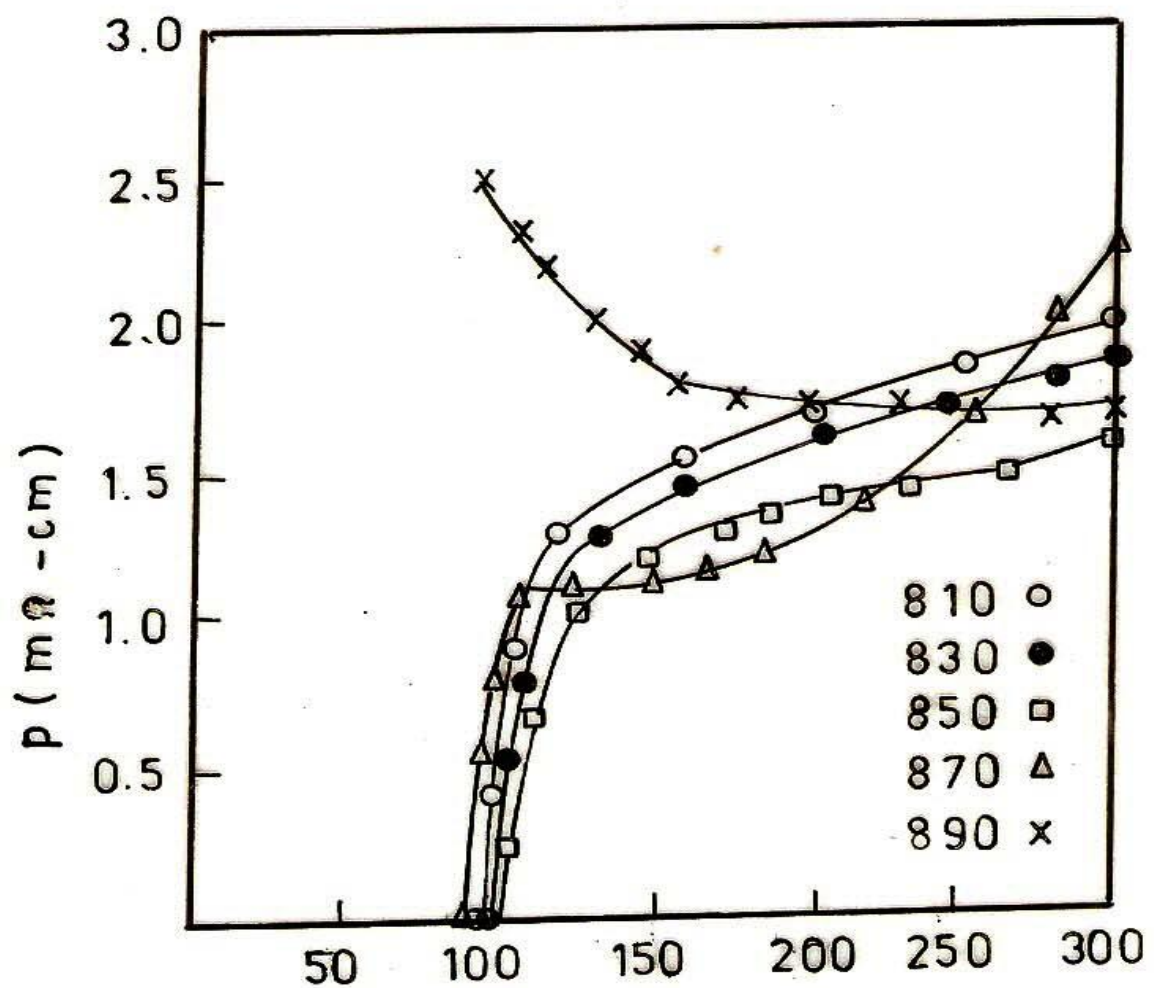

Fig(2): The resistivity versus Temperature

$\mathrm{Bi}_{2} \mathrm{Ba}_{2} \mathrm{Ca}_{2} \mathrm{Cu}_{3} \mathrm{O}_{10+\delta}$ at different temperatures

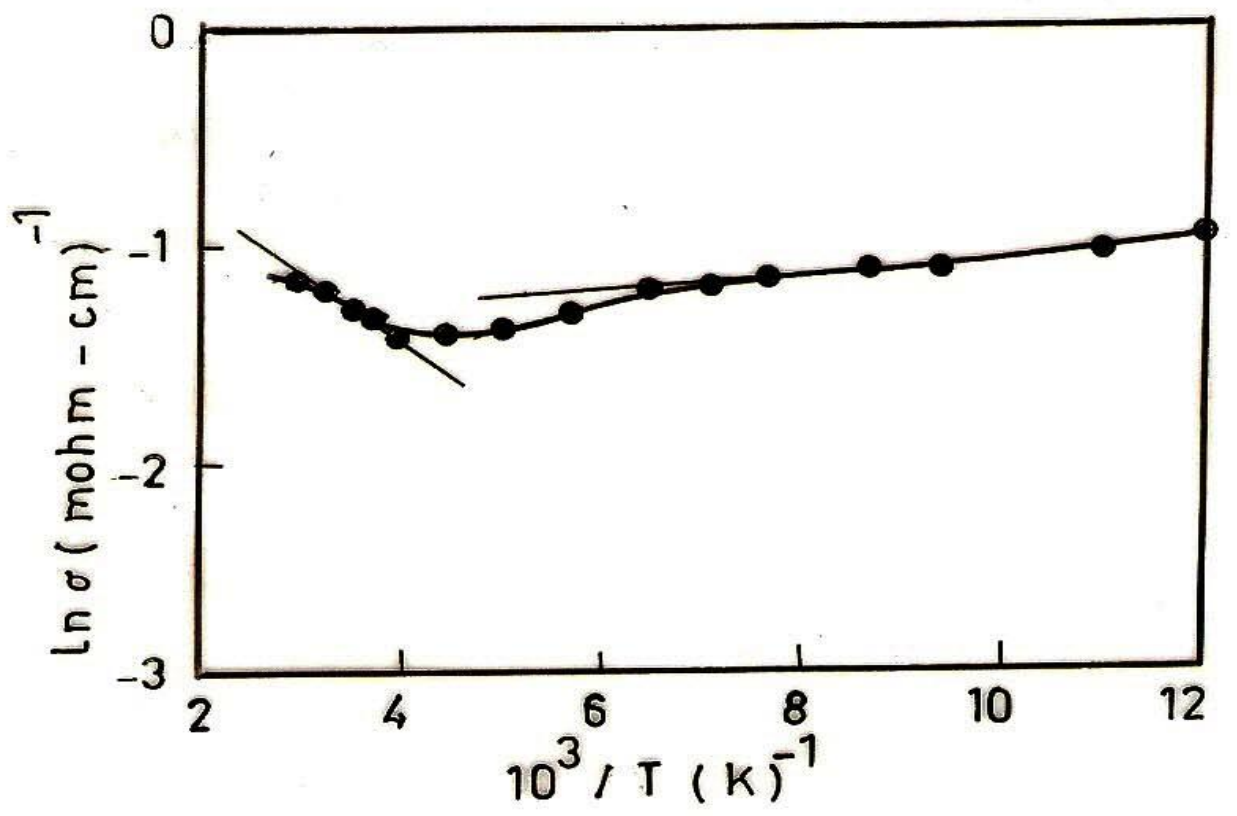

Fig(3): The conductivity versus Temperature $\mathrm{Bi}_{2} \mathrm{Ba}_{2} \mathrm{Ca}_{2} \mathrm{Cu}_{3} \mathrm{O}_{10}$ at $890^{\circ} \mathrm{c}$ 


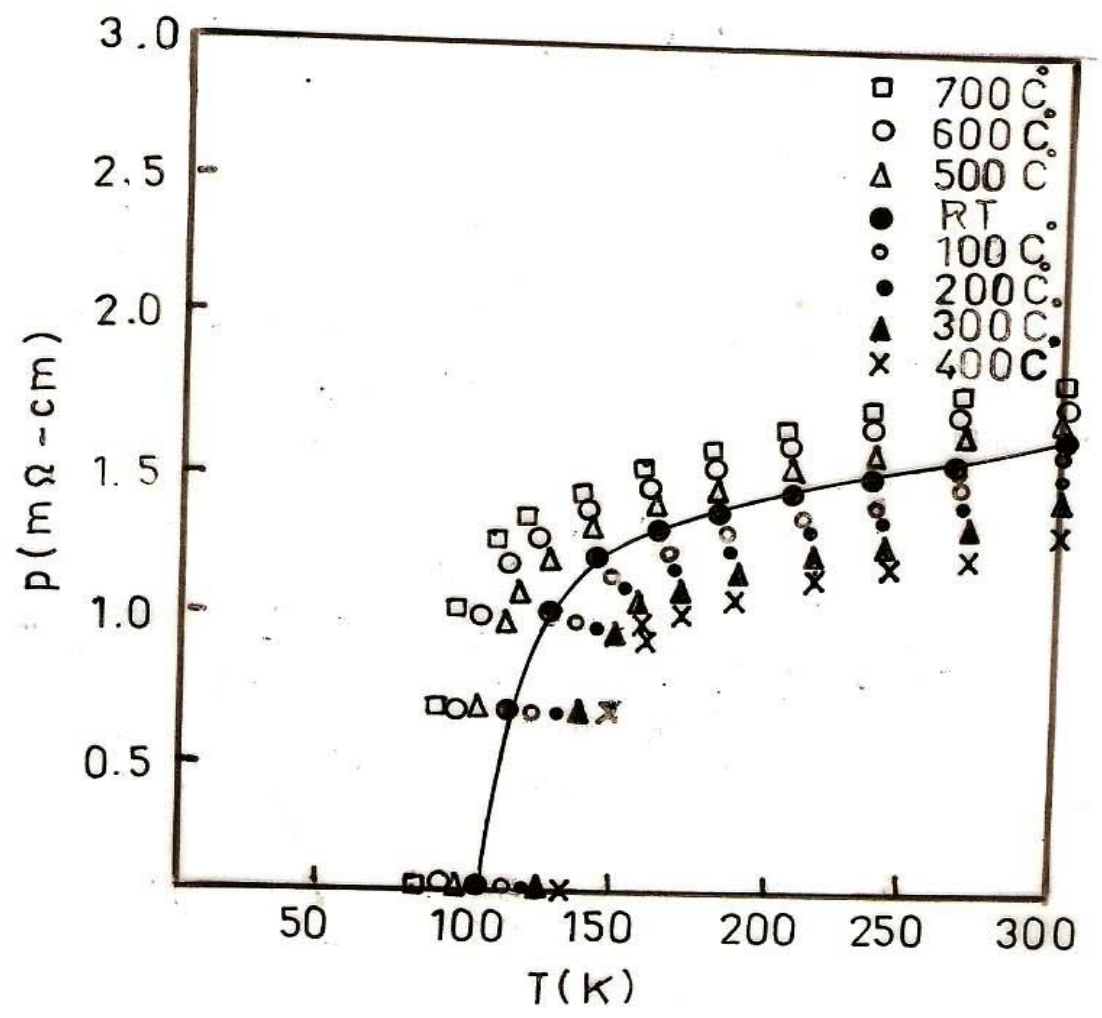

Fig(4) The resistivity versus Temperature $\mathrm{Bi}_{2} \mathrm{Ba}_{2} \mathrm{Ca}_{2} \mathrm{Cu}_{3} \mathrm{O}_{10}$ at $850^{0}$ with different annealing temperature.

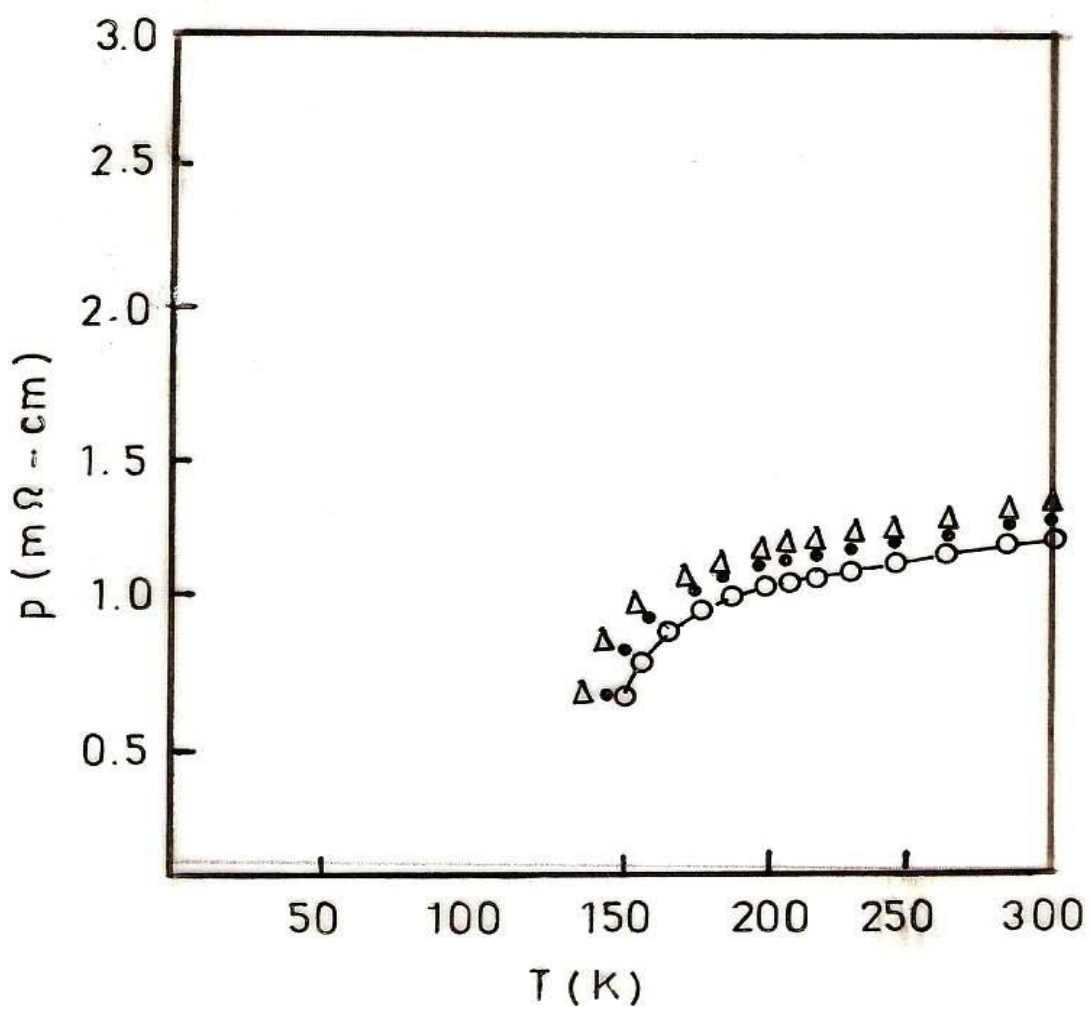

$\operatorname{Fig}(5)$ The resistivity versus Temperature $\mathrm{Bi}_{2} \mathrm{Ba}_{2} \mathrm{Ca}_{2} \mathrm{Cu}_{3} \mathrm{O}_{10}$ at $850^{\circ}$ with annealing temperature $4000 \mathrm{c}$ at different time. 


\section{References:}

1) Michel, C., Hevicu, M., Borel, M., Grantin, F. and Reveau. B. Z. phys. 421. B68 (1987).

2) Meada, M., Teanaka, Y., Fukutoml, M. and Asano, A. Jpn. J. Appl. Phy. 27, L209 (1988).

3) Chu, C., Bechtold, J., Hor, P. and Xuc, Y. Phy. Rev. Lett. 941, 60 (1988).

4) Hazen, R. and Sun, Y. Phy, Rev. Lett 881, 60 (1988).

5) Rao, C., Chemistry of oxide superconductors, Sci. publi. oxford (1988).

6) Fathi,S. and Al-Jobouri,S. J. Educ. and Sci. (20)22, (1994).

7) A. El. Ali (Al-Dairy), A. D. Alazawi, Y. A. Hamama, J. J. p vol.(1), No.(1) pp 43-52(2007).

8) A. D. Ali phD Thesies, University of mousl" " (2007).

9) S. H. Salahdine, Msc. Thesies university of Tikrit (2008) "Partial effect and Electrical propertries - HTSC of $\mathrm{Bi}_{2-\mathrm{k}} \mathrm{Hg}_{\mathrm{k}} \mathrm{Ba}_{2} \mathrm{Ca}_{2}$ $\mathrm{Cu}_{3} \mathrm{O}_{10+\delta}$ ".

10) Subramanina, M. and Morrissey, K. Mod, Phy. Lett 95, B4 (1990).

11) Putilin, S., Antipov, E., Chmaissem, O. and Marezio, M. Nature 362, 226, (1993).

12) Li, J., Ding S, Zhu,J. and Wang, Y. J. Appl. Phy. 77, 3698 (1995).

13) Asab, A., Armstrong, A., Gameson, I. and Edwards, P. Physica. C 255. 180 (1995).

14) Mahamad, N., Fathi, S. and Fathulla, M. J. Edu. Sci. (2002).

15) Fathi, S., Alwahab, M. and Zainal, K. J. Edu. Sci. (30)16, (1998). 